\title{
The Enhanced Role of Diet in Crohn's Disease
}

\author{
Rima Khabbaz* \\ National Center for Emerging and Zoonotic Infectious Diseases, Georgia
}

Submission: February 02, 2017; Published: March 21, 2017

"Corresponding author: Rima Khabbaz, Centers for Disease Control and Prevention, National Center for Emerging and Zoonotic Infectious Diseases, 1600 Clifton Road, GA 30329, Atlanta, Georgia, Email: GMonif@aol.com

\section{Opinion}

Dietary interventions have focused on reversing the disease induced catabolic state and identification of foods that exacerbate symptoms.

The Hruska Postulate identifies Crohn's disease (CD) as the consequence of two inter-related actions involving Mycobacterium avium subspecies para tuberculosis (MAP). The potential for CD is created when a newborn, lacking effective acquired immunity, has to deal with infection by MAP. The consequence of arresting MAP replication results in fixation of the pro-inflammatory cytokine response to MAP and the loss of immunological tolerance. The clinical manifestation of $\mathrm{CD}$ is contingent upon repeat MAP antigen challenges and the elicited cytokine responses that, in time, overwhelm the regenerative capacity of the lining gastrointestinal mucosa [1,2].

The genesis of dietary intervention in CD is not new. Without understanding the events that combined to produce disease, Crohn's afflicted individuals had previously identified individual foods that exacerbated their symptoms. This information became integrated into what are termed dietary intervention regimens.

Crohn's disease exclusion diets evolved primarily from small nonrandomized clinical trials. Chiba reported that 94\% of Crohn's afflicted individuals who remain on a semi-vegetarian diet maintained in clinical remission whereas $33 \%$ of individuals who returned to a regular diet relapsed [3]. Sigall-Boneh reported that $70 \%$ of Crohn's afflicted individuals achieved clinical remissions on a Crohn's disease exclusion diet. What was impressive in his data was the number of individuals who achieved normalization of their C-reactive levels [4].

Identifying MAP as the trigger antigen of an immune-mediated disease allows construction of CD exclusion diets whose therapeutic potential can be augmented by specific nutritional supplementation to convert temporary remissions to permanently sustained remissions [5].
An unintended experiment documented that stress reduction and target nutrition resulted in total eradication of MAP massive infection in a cow (Johne's disease) that should have been terminal [6]. The advertent result was total destruction of MAP and reversal of gross and histologic evidence of disease. The cellular marker left in place identified the mechanism by which the immune system destroys MAP. Previously, Johne's disease had been deemed incurable. That dietary supplementations that targeted enhancement of cell-mediated immunity, coupled with stress reduction, could empower the immune system to, not suppress replication, but actually destroy MAP brought into focus the potential of immune enhancing dietary intervention to expand its conceptual role from an adjunctive to a therapeutic modality.

Once an individual experiences diarrhea for a sustained period of time, his or her immune system becomes progressively compromised. In Crohn's disease, the mucosal tissue destruction and inflammatory infiltration of the lamina propria constitute impediments to absorption of substances from the gastrointestinal tract. Semi-vegetarian diets and the IDI immunotherapeutic formulation for Johne's disease share a number of key elements that are necessary for optimal immune system function. Some of these elements, zinc, selenium, Vitamins C, D, and E, are reduced in chronic diarrheal diseases.

\section{Zinc}

Crohn's disease results in decreased zinc absorption and increased exogenous loss $[7,8]$.The body has no specialized system to store zinc. Individuals with Crohn's disease have zinc deficiency impairment affecting a broad spectrum of mechanisms involved in the killing of intra-cellular pathogens [9,10]. Interlukin-1 (IL-1) tumor necrosis factor (TNF) and interlukin-6 (IL-6) cause a marked decrease in serum zinc concentration [11,12]. Among the major functional consequences of zinc deficiency are anorexia, diarrhea, and impaired immunological responsiveness. 


\section{Selenium}

Selenium is an essential component of selenocyteine proteins within the immune system. Selenium dependent glutathione peroxidases protect neutrophils from oxygen-derived radicals and act as an anti-oxidase in the extra-cellular space [13]. Vitamin E deficiency is frequently concomitantly present in selenium deficient animals [14]. Deficiency of selenium undermines the integrity of the gastrointestinal mucosa by facilitating the action of proinflammatory compounds.

\section{Vitamin D}

Vitamin D3's active form plays an important role in cell differentiation and proliferation of the immune system. It suppresses cell proliferation that results in a shift from a TH1 to TH2 response, skews T cell maturation away from TH17, and inhibits monocyte production of pro-inflammatory cytokines IL-1, IL-6, IL-8 IL-12 and TNF alpha $[15,16]$. In Crohn's disease,symptom amelioration to actual transient remission has been observed following aggressive vitamin D supplementation.

\section{Vitamins C \& E:}

Vitamin C regenerates vitamin E from its oxidized form. The lipid soluble antioxidant vitamin E not only protects the integrity of cell membranes, but functions synergistically with other nutritional elements that beneficially influence cell-mediated immunity [1719]. The salvage of vitamin $E$ influences the immune functions of selenium which in turn has a beneficial impact on copper and zinc utilization. The body has no specialized system to store Vitamin C.

The dietary therapeutic objectives in CD are:

A. Elimination of all foods potentially adulterated by MAP.

B. Restoration of an anabolic metabolism in Crohn's afflicted individuals.

C. Utilization of targeted dietary supplementation to enhance cellular immunity.

Given the ability to affect MAP, Immune system targeted dietary supplementation stands to be a powerful co-therapy with antimicrobials in destroying the template that sustains the body's dysfunctional pro-inflammatory response to the antigens of MAP.

\section{References}

1. Hruska K (2015) Crohn's disease and related inflammatory diseases: from a single hypothesis to one superhypothesis. Veterinarni Medicina 59(12): 583-630.
2. Monif GRG (2015) The Hruska postulate. Med Hypothesis 85(6): 87888.

3. Chiba M, Abe T, Tsuda H, Sugawara T, Tsuda S, et al. (2010) life-stylerelated diseases in Crohn's disease: relapse prevention with semivegetarian diet. World J Gastroenteriol 16(20): 2484-2495.

4. Sigall-Bonch R, Pfeffer-Gik T, Segal I, Zangen T, Boaz M, et al. (2014) Partial enteral nutrition with Crohn's disease exclusion diet is effective for induction of remission in children and young adults with Crohn's disease. Inflam Bowel Dis 20(8): 1353-1360.

5. Monif GR (2016) Translation of hypothesis to therapy in Crohn's disease. J Bowel Dis Disorders 22(2): E8-E9.

6. Monif GRG, Williams JE (2015) Relationship of intestinal eosinophilia and acid-fast bacilli in Johne's disease. Intern J Appl Res Vet Med 13(2): 147-149.

7. Valberg LS, Flanagan PR, Kerteszy A, Bondy DC (1986) Zinc absorption in inflammatory bowel disease. Dig Dis Sci 31(7): 724-731.

8. McClain CJ, Soutor C, Zieve L (1980) Zinc deficiency; a complication of Crohn's disease. Gastroenterol 78(2): 272-279.

9. Powell S (2000) The anti-oxidant properties of zinc. J Nutr 130: 1447S-1454S.

10. Prasad AS (2000) Effects of zinc deficiency on Th1 and TH2 cytokine shifts. J Infect Dis 182: S62-S68.

11. Rink L, Gabriel P (2000) Zinc and the immune system. Pro Nut Socs $144-1540$

12. Gaetke L, McClain CL, Talwalkar R, Shedlosky S (1997) Effects of toxins on zinc metabolism in human volunteers. Am J Phtsiol 272: 952-956.

13. Arthur JR, McKenzie RC, Beckett GJ (2003) Selenium in the immune system. J Nutri 133: 1457s-1459s.

14. Wichtel JJ (1998) A review of selenium deficiency in grazing animals. Part 1 N Z Vet J 46(2): 47-52.

15. Webb AL, Villamor E (2007) Effects of antioxidants and non-oxidant vitamins on the immune system. Nutr Rev 65: 181-217.

16. Hogan JS, Weiss WP, Smith KL (1993) Role of vitamins and selenium in host immunity against mastitis. J Dairy Sci 76(9): 2795-2803.

17. Girodon F, Galan P, Monget AL, Boutron -Ruault MC, Preziosi P, et al. (1999) Impact of trace elements and vitamin supplementation on immunity andinfection in the elderly institutionalized patients. Arch. Intern. Med 159(7): 748-754.

18. Winstergerst ES, Maggini S, Horning DH (2006) Immune-enhancing role of vitamin $\mathrm{C}$ and zinc and effect on clinical conditions Ann. Nutr. Metab 50(2): 85-94.

19. Banc S (1982) Immunostimulation by vitamin C. Int J Vitam Nutr Res 23: 49-52. 
(C) Commons Attribution 40 This work is license

(C) DOI: $10.19080 /$ ARGH.2017.04.555629

\section{Your next submission with Juniper Publishers} will reach you the below assets

- Quality Editorial service

- Swift Peer Review

- Reprints availability

- E-prints Service

- Manuscript Podcast for convenient understanding

- Global attainment for your research

- Manuscript accessibility in different formats ( Pdf, E-pub, Full Text, Audio)

- Unceasing customer service

Track the below URL for one-step submission https://juniperpublishers.com/online-submission.php 